\title{
Examining Apology and Culture: Interpersonal and Intergroup Apologies in Turkey
}

\author{
Dr. Veysel Mehmet Elgin1,2 (elgin_v@ibu.edu.tr) \& Prof. Dr. Ayşe K. Üskül2 (a.k.uskul@kent.ac.uk) \\ 1 Department of Psychology, Bolu Abant Izzet Baysal University, Bolu, Turkey \\ ${ }_{182}$ School of Psychology, University of Kent, Canterbury, UK
}
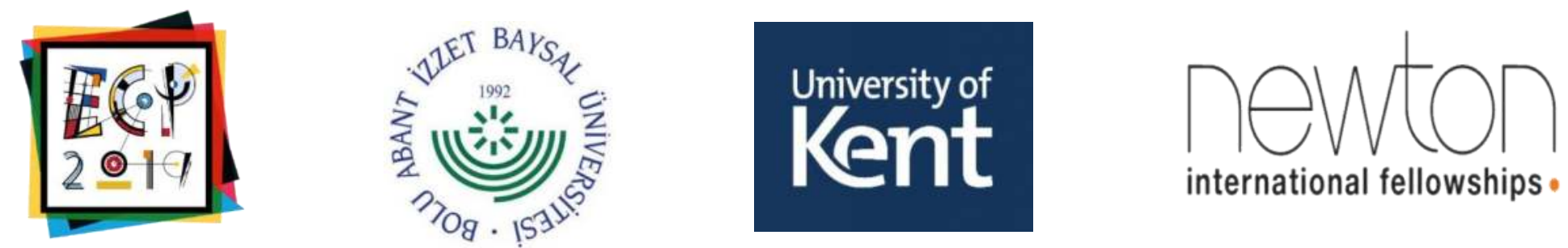

\section{INTRODUCTION}

Apology is a significant tool for reconciliation (Lazare, 2004). However, the prevalence and perception of apologies may differ across cultural groups. Accordingly, this research examines apologies within an honor culture (Turkey) where positive social image and reputation of strength are important driving sources of psychological processes (Nisbett \& Cohen, 1996; Uskul \& Cross, 2019). In addition, offering an apology may be perceived as a threat to one's social image, implying a weak position (Mills, 2001; Schumann, 2018).

\section{OBJECTIVE}

Given the importance of positive social image in honor cultures, this research aims to examine whether honor culture members view apology offers negative and use them infrequently.

\section{STUDIES}

\section{METHODS}

\section{FINDINGS}

Out of 2667 proverbs and 6310 idioms, only two idioms contain a direct reference to idioms (retrieved from two major Turkish proverb and idiom books by Aksoy, 2014, 2015).
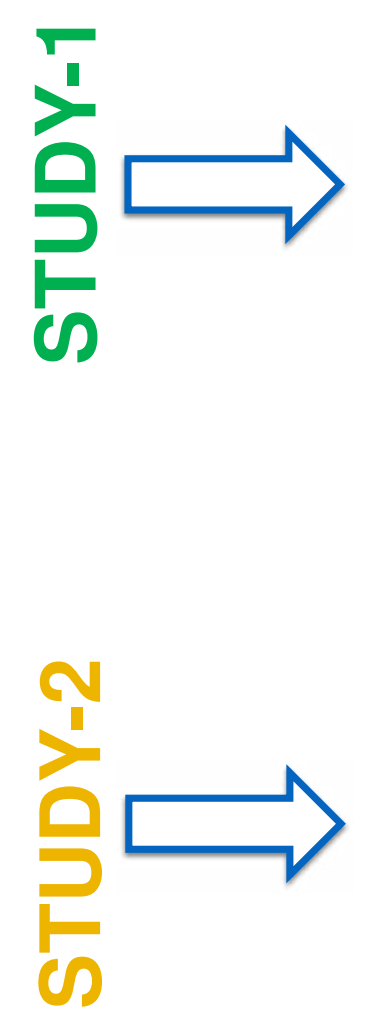

Screening Turkish news published in Google and the main Turkish news agency (Anadolu Agency) in the first five months of 2018 for news referring to an $\square$ intergroup/collective apology (i.e., on behalf of a group) or interpersonal apology (i.e., on behalf of oneself) offered by politician or non-politician figures in Turkey.

$>$ apology (e.g., One's apology offer is worse than the original wrongdoing). However, there are proverbs and idioms $(n=25)$ that imply apologizing in some other forms (e.g., seeking forgiveness).

\begin{tabular}{|l|cc|}
\hline $\begin{array}{l}\text { Frequency of Offering Apologies in Turkish Media within the first } \\
\text { five months of } 2018\end{array}$ & $\frac{\text { Politicians }}{2}$ & $\frac{\text { Non-Politicians }}{24}$ \\
Offering Intergroup/Collective Apology & 9 & 59 \\
\hline Offering Interpersonal Apology & 8 & 93 \\
\hline Total & 17 & 110 \\
\hline
\end{tabular}

Given the significance of proverbs and idioms in reflecting the historical and current characteristics of a society (Özkan \& Gündoğdu, 2011), it can be claimed that apologies do not appear as a salient factor in Turkey. Besides, compared with other cultural studies based on proverbs and idioms (i.e., Elgin, 2017), apology issue -including forgiveness- seems not to take much place in Turkish culture.

A quantitative study with 196 Turkish undergraduates (169 women, $M_{\text {age }}=20.73, S D_{\text {age }}=2.15$ ) by using 7-point Likert scales (1: Definitely Disagree, 7: Definitely Agree). Variables:

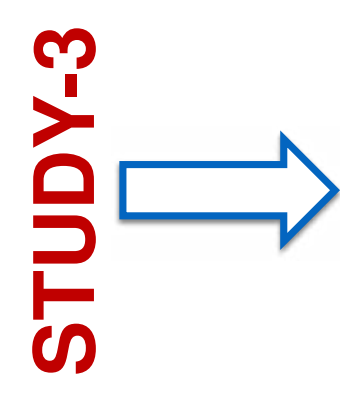

Apology as moral virtue: "Offering apology is a moral virtue."

- Perceived weakness of offering apology in Turkish society: "Offering apology is seen as weakness in our society."

- Frequency of offering apology in Turkey: "Apologies are generally offered after a wrongdoing in our society."

- Opposing Government's Collective Apology Offer (5 items): (e.g.,

"Turkish State should not offer apology to any country at all costs."

- Social Identity (5 items): (e.g., "Being a Turkish citizen is an important part of my identity.")

- Collective Honor: "IImportance of] Turkey's social image in the world" (1: not important at all; 7: extremely important) i) Offering apology is considered to be a moral virtue $(M=6.68, S D=.71)$.

ii) Offering apology is seen as somewhat weakness in Turkey $(M=4.91, S D=1.80)$.

iii) Offering apology for a wrongdoing is not perceived to be common $(M=2.70, S D=1.57)$.

\begin{tabular}{|l|c|c|c|}
\hline $\begin{array}{c}\text { iv) } \\
\text { Correlation } \\
\text { Matrix }\end{array}$ & $\begin{array}{c}\text { Collective } \\
\text { Honor }\end{array}$ & $\begin{array}{c}\text { Social } \\
\text { Identity }\end{array}$ & $\begin{array}{c}\text { (3) Opposing } \\
\text { Government's } \\
\text { Collective } \\
\text { Apology } \\
\text { Offer }\end{array}$ \\
\hline$(1)$ & & & \\
\hline$(2)$ & $.47^{* *}$ & & \\
\hline$(3)$ & $.18^{*}$ & .10 & \\
\hline
\end{tabular}

Coding apologies by source revealed that politicians are less likely to offer apologies compared to non-politicians within the first five months of 2018 in Turkey. In addition, it was found that intergroup/collective apologies are less likely to be offered compared to interpersonal apologies in Turkey. 